University for Business and Technology in Kosovo

UBT Knowledge Center

UBT International Conference

2017 UBT International Conference

Oct 27th, 4:45 PM - 6:15 PM

\title{
Monitoring of air quality in the urban and industrial areas in Kosovo
}

\author{
Besa Veseli \\ University for Business and Technology, besa.vaseli@ubt-uni.net \\ Sami Gashi \\ University for Business and Technology, sami.gashi@ubt-uni.net \\ Shkumbin Shala \\ University for Business and Technology, shkumbin.shala@ubt-uni.net
}

Follow this and additional works at: https://knowledgecenter.ubt-uni.net/conference

Part of the Bioresource and Agricultural Engineering Commons

\section{Recommended Citation}

Veseli, Besa; Gashi, Sami; and Shala, Shkumbin, "Monitoring of air quality in the urban and industrial areas in Kosovo" (2017). UBT International Conference. 133.

https://knowledgecenter.ubt-uni.net/conference/2017/all-events/133

This Event is brought to you for free and open access by the Publication and Journals at UBT Knowledge Center. It has been accepted for inclusion in UBT International Conference by an authorized administrator of UBT Knowledge Center. For more information, please contact knowledge.center@ubt-uni.net. 


\title{
Monitoring of air quality in the urban and industrial areas in Kosovo
}

\author{
Besa Veseli ${ }^{1}$, Sami Gashi ${ }^{2}$ Shkumbin Shala ${ }^{3}$ \\ ${ }^{1,2,3}$ UBT- Higher Education Institution, Lagjja KALABRIA p.n., Prishtinë, Kosovë \\ besa.veseli@ubt-uni.net, sami.gashi@ubt-uni.net
}

\begin{abstract}
Environmental pollution has a direct or indirect effect, and is mainly caused by human activity or environmental processes that have harmful effects in the environment and human life. In Kosovo the air pollution in Kosovo is quite evident in the industrial areas. The power plant of KEK (TCA and TCB), from the Cement Factory and ferronickel etc. In the vast majority of cases, the pollution is caused by the emission of sulfur dioxide (SO2), azotes (NOx), ozone, lead and other heavy metals, such as carbon monoxide (CO), dust, PM10,PM2,5 and steamy organic components. The aim of this inquiry is to study the air pollution in urban and industrial areas and to take further measures for estimation of air emissions. This scientific paper will with analyze the effect of ferronickel in environment and the facilities in Kosovo Energetic Corporation as the main cause air pollution in urban areas. Based on the arguments provided from this study it is concluded that the main pollutants in urban and industrial areas are the power plants (Kosova A and Kosova B). industrial complex of Mitrovica, the circulation of cars in urban areas, Ferronickel in Drenas, the Cement Factory Sharcem of Han iElezit. The process of monitoring the air quality it is conducted by the Hydro-Meteorogical Institute and some of the economic operators such as Ferronickel and KEK.
\end{abstract}

Key words: monitoring air quality, air pollution, urban and industrial areas

\section{Introduction}

In Kosovo, the quality of air is damaged in developed urban areas and especially in industrial areas. In Kosovo, the greatest impact on the environment is caused by KEK power plants (TCA and TCB), Feronikeli, Sharrcemi, other plants with small capacity and heating system. A great concern for environmental pollution is also inherited industrial waste and urban waste dump, etc. The most influential areas in the environment are the areas where the thermo-energy and metallurgical as well; Obiliq, Drenas, Mitrovica, Pristina, Hani i Elezit

Today, the industry in the country is mostly polluted by sulfur dioxide ( $\mathrm{SO} 2$ ) emissions, nitrogen oxides (NOx), ozone (O3), lead $(\mathrm{Pb})$, carbon dioxide (CO2), dust, smoke, particles PM10, PM2.5, volatile organic compounds VOCs) and dioxins.

In fossil fuel facilities, mainly fossil fuels are used, such as coal and high sulfur compound oil derivatives. The transport sector is characterized by a large number of outdated vehicles and the use of low quality fuels (in most cases). In addition, the industry sector in most cases uses old equipment. The agriculture sector contributes to air pollution mainly through the burning of biomass. Areas where their waste and uncontrolled burns are thrown out represents a serious source of air pollution.

In addition, the sources of pollutant emissions in the air comes from all industrial and commercial categories, other activities, motor vehicles and also sources from biogenic vegetation emissions. In Kosovo, the quality of air is damaged in the developed urban areas, especially in industrial areas. The greatest impact on the environment is caused by KEK's thermal power plants (TCA 
and TCB), industries (metallurgy, mines, cement factories, etc.) and small ones, but pollution is also caused by individual heating facilities. Mitrovica is also counted among the major sources of pollution basen on the consequences of industrial waste left over from the Trepça complex,.

\section{Material and methods}

The measurements were made at the automatic air quality monitoring station located at the IHMK site, which is equipped with automatic analyzers of sulfur dioxide ( $\mathrm{SO} 2)$, nitrogen oxides (NOx), carbon monoxide (CO ), ozone (O3), suspended particulate analyzer PM10 / PM2.5 (with fractionator for PM10 and PM2.5, depending on which faction is placed to be monitored). While the data for the city of Drenas were taken from the air monitoring station in Drenas.

The purpose of this study is to present the data on atmospheric pollution in the cities of Pristina and Drenas and the factors that influence the environmental pollution. These parameters have been measured: sulfur dioxide (SO2), nitrogen oxides (NOx), carbon monoxide (CO).

\section{Results and discussions}

Assessment of NO2 pollution Nitrogen dioxide (NO2) as well as Sulfur dioxide (SO2) are an integral part of smog and causes of acid rain. They are generated by combustion of coal, oil and its derivatives. Each of them penetrates very easily into the human body and can cause lung disease, and increase the likelihood of viruses, as well as irritation of eyes or skin. The presence of $\mathrm{NO} 2$ in urban areas is mainly due to the increase in road and rail transport.

The table below shows the average annual NO2 concentration values against the allowed average annual value.

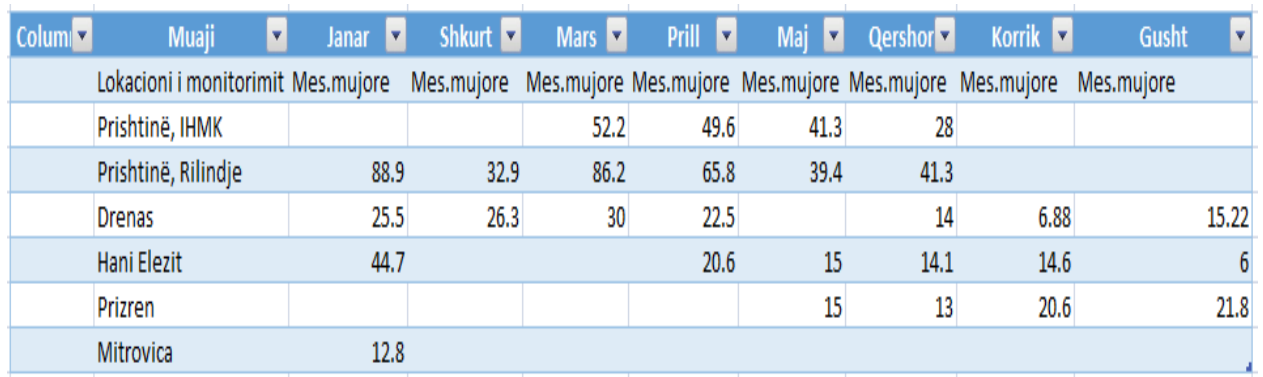




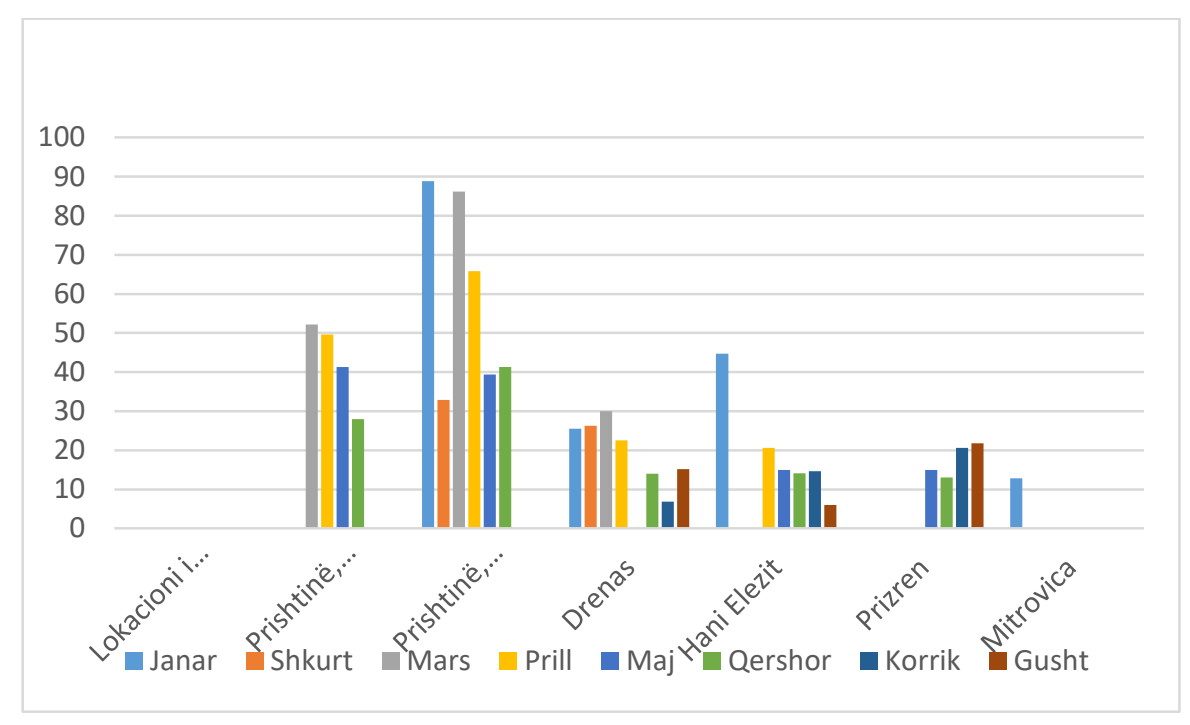

\section{Assessment of air pollution by sulfur dioxide (SO2)}

Sulfur dioxide is released from burning fossil fuels (industry, households, transport). Sulfur dioxide causes acidification of soils, streams and lakes and affects damage to construction materials, including cultural heritage.

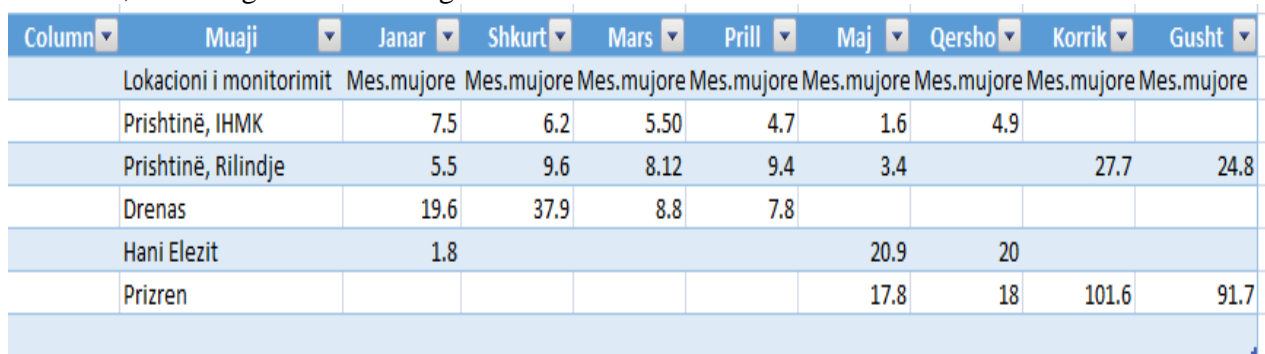




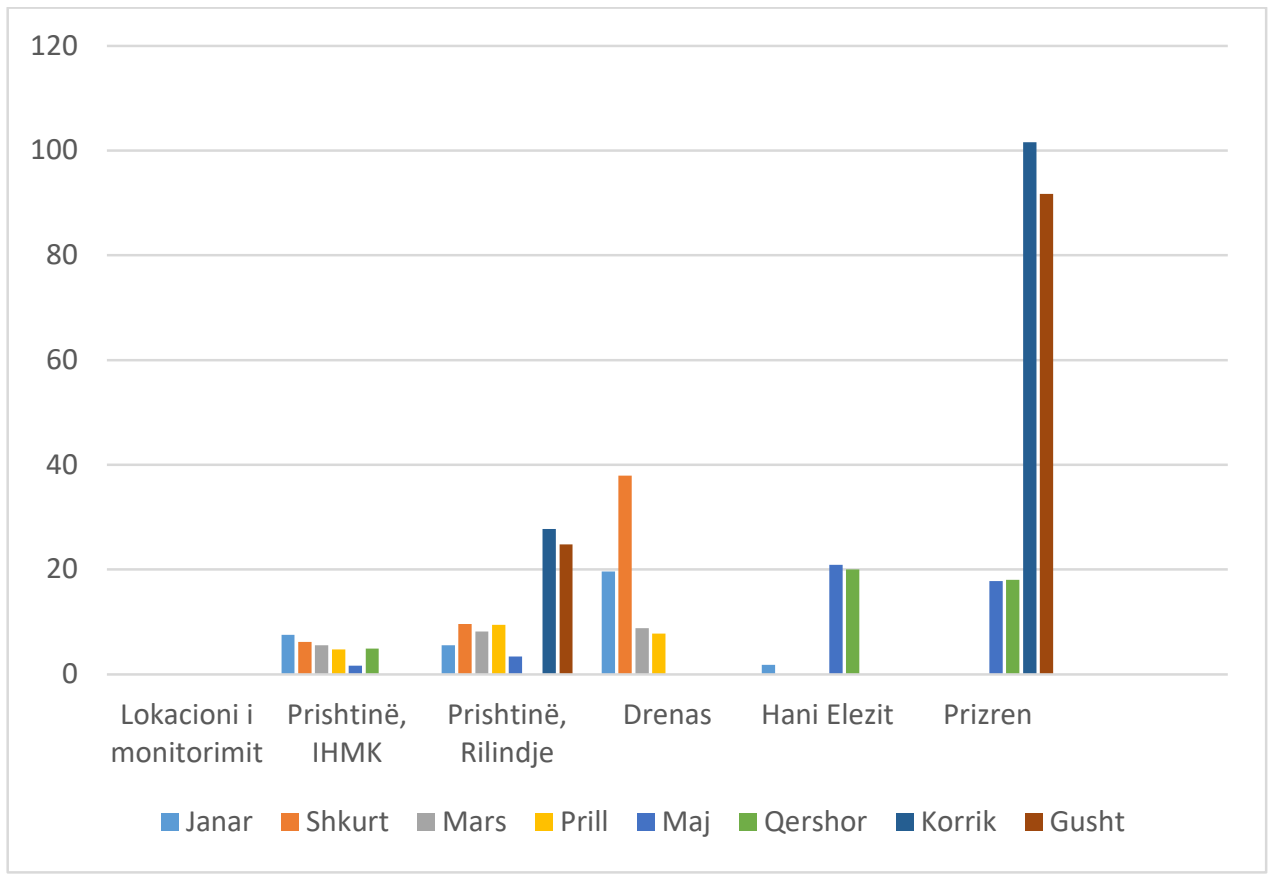

\section{Air Pollution Assessment by Carbon Monoxide CO}

The main sources of $\mathrm{CO}$ air pollution are: Vehicles (as the largest $\mathrm{CO}$ emission), fuel burning (coal burning, liquid fuels, natural gas and wood) Industrial processes (refineries, furnaces, paper factories and facilities for the production of construction materials).

The high concentration of CO can provoke many pathological changes in people (in the blood, nerves, sight, etc.) and can cause death. Data have shown that $\mathrm{CO}$ concentration in the air between $7.8 \mathrm{ppm}-13.9 \mathrm{ppm}$ increases the number of deaths by heart attack.

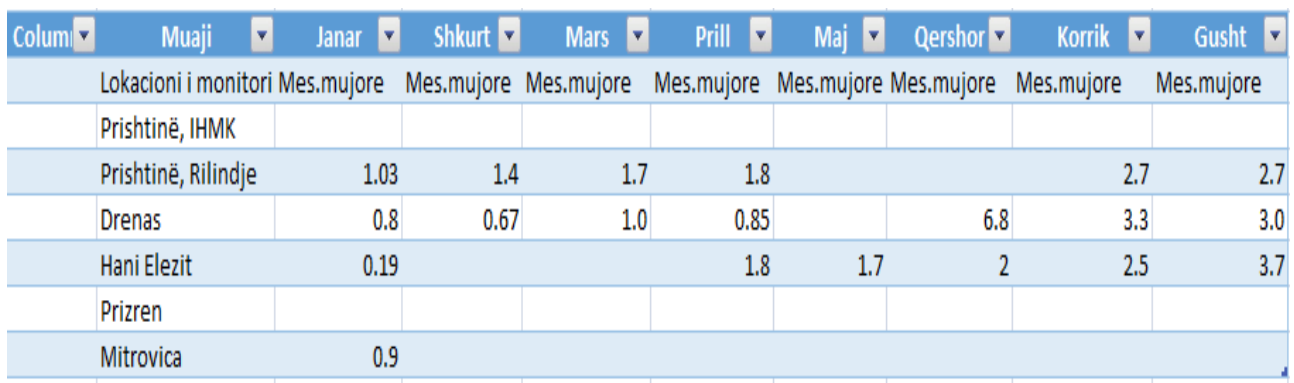




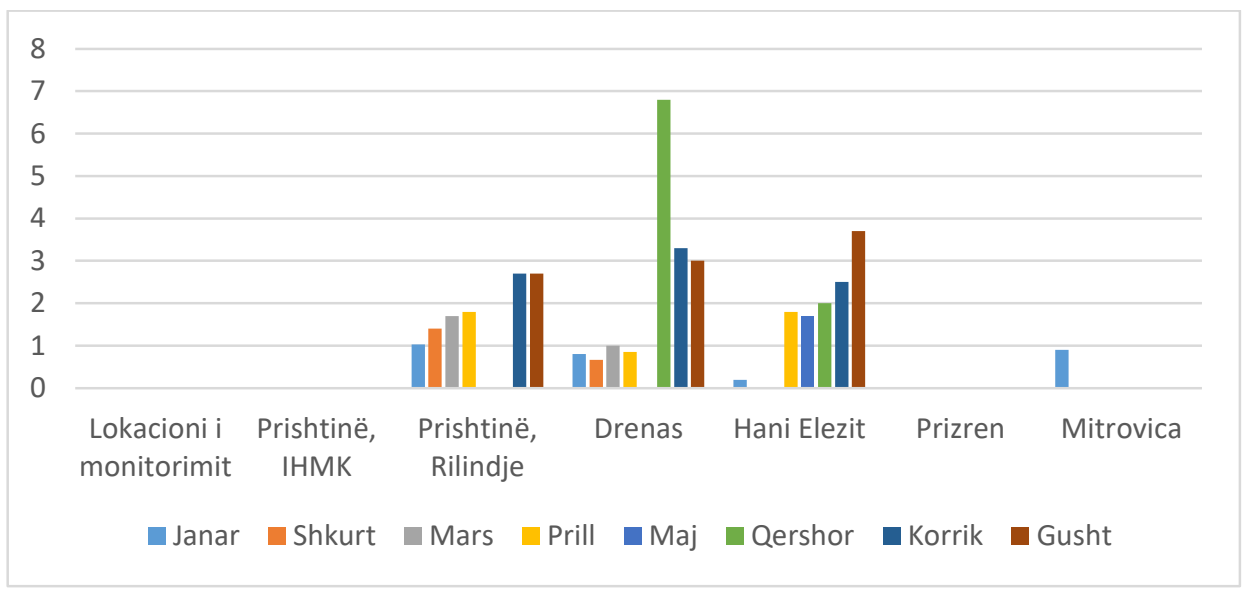

Ozon O3 (ug/m3)

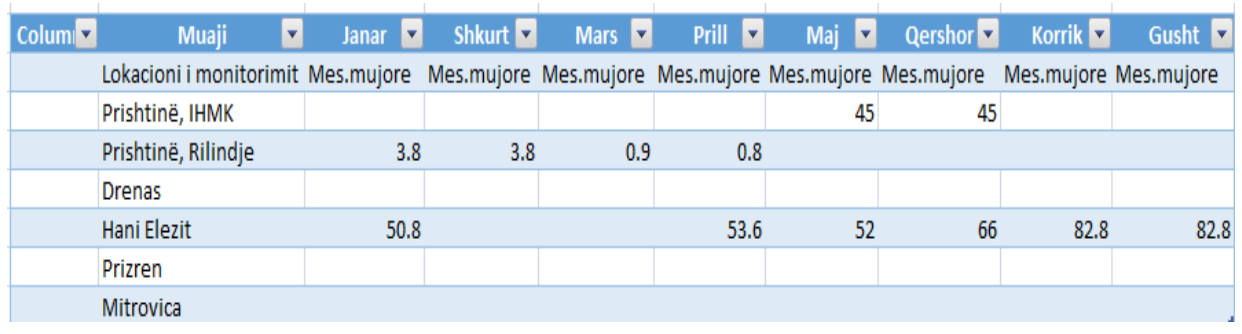

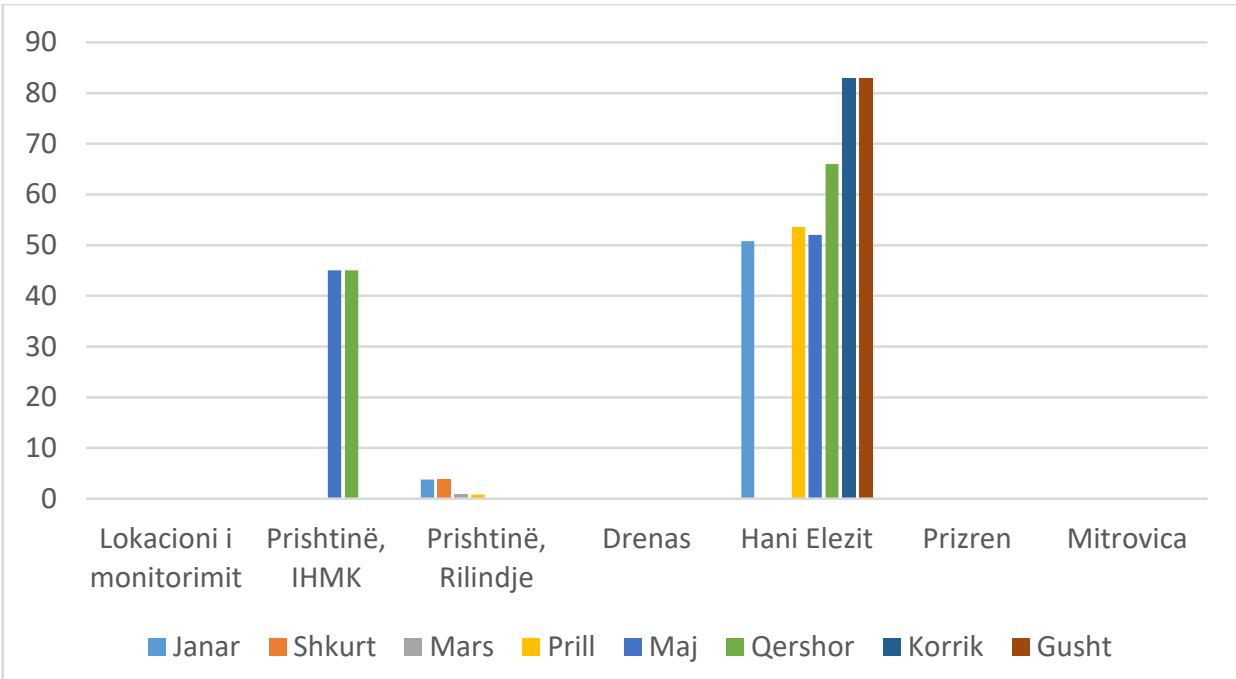




\section{Suspended PM 10 particles $(\mu \mathrm{g} / \mathrm{m} 3)$}

PM particles are particles found in the air that include dust, soot, smoke, and liquid droplets. Particles can stick to the air for long periods of time. Some particles are large that can be seen through the eyes like soot, dust or smoke. Others are so small that can only be detected with an electronic microscope.

Many artificial sources (operator, industry, transportation, etc.) and natural emits PM directly to the environment or emit other pollutants that react to the atmosphere to form PM. These solid and liquid particles come in a wide range of sizes

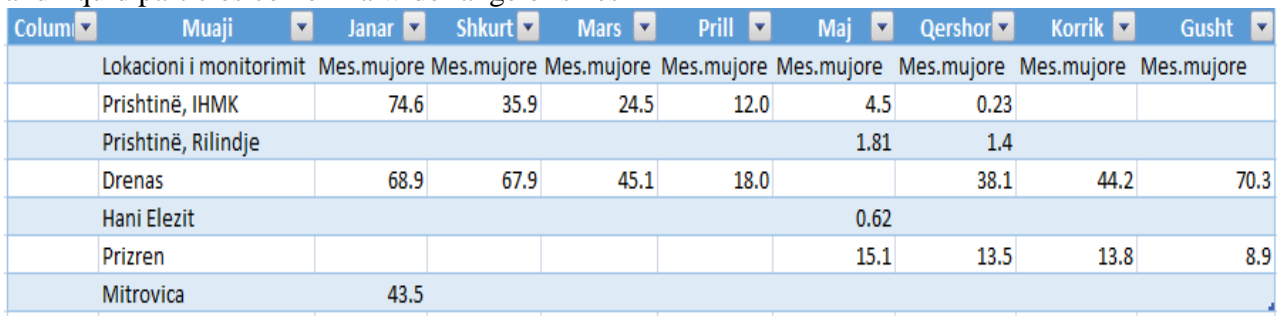

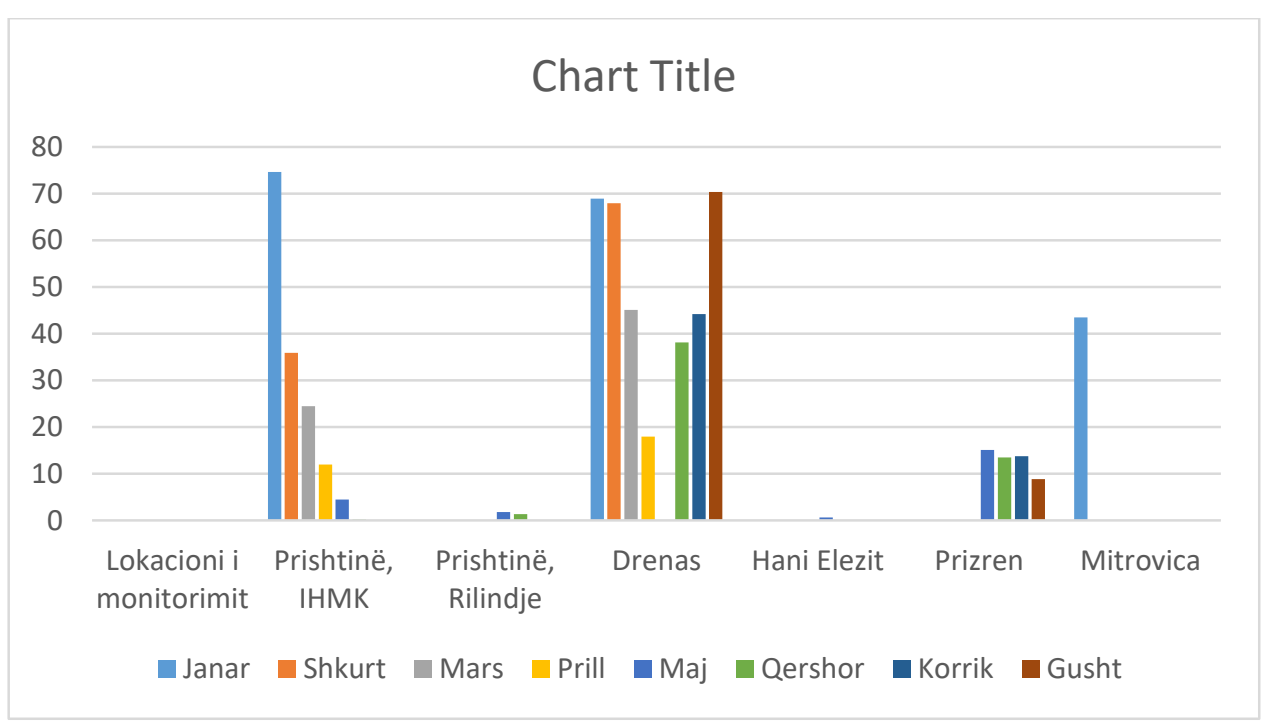




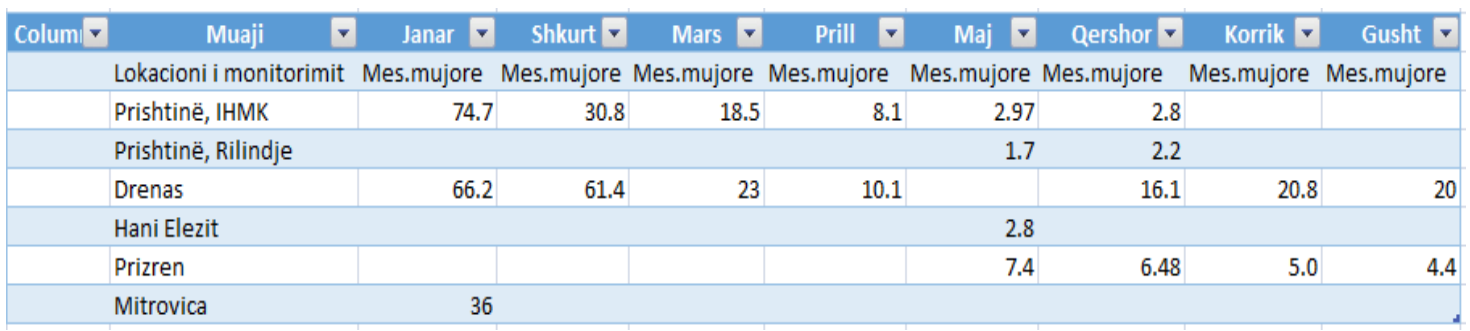

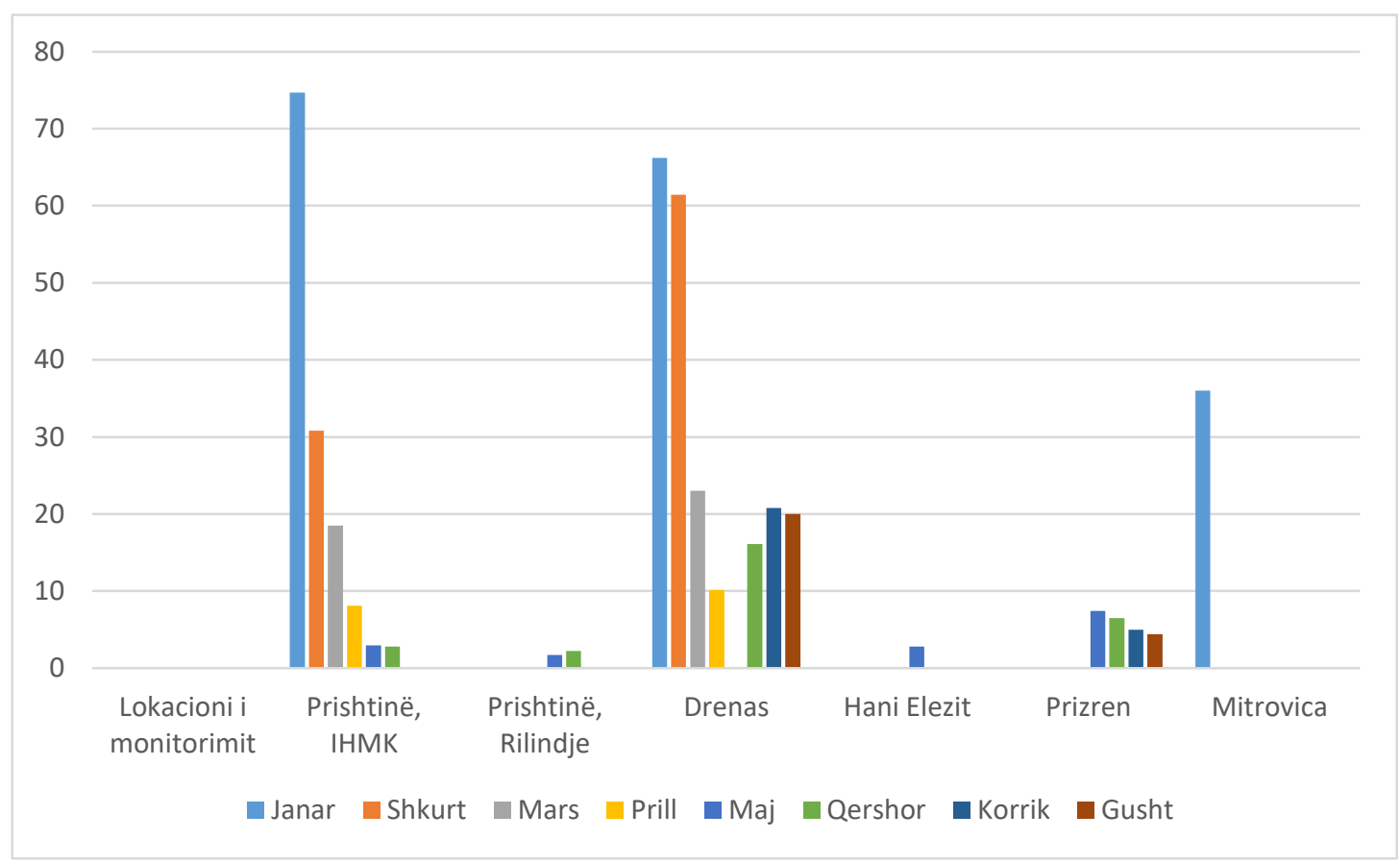

\section{Conclusions}

The rapid economic and social changes in our country after the 1999s were accompanied by significant changes in the structure of air pollution and pollution sources. In most cases, pollution occurs in the form of sulfur dioxide (SO2) emissions, nitrogen oxides (NOx), ozone (O3), lead $(\mathrm{Pb})$ and other heavy metals, carbon monoxide $(\mathrm{CO})$, dust, smoke, particulate matter PM10, PM2.5, volatile organic compounds (KOA / VOCs), dioxins, etc.

The annual average $(\mu \mathrm{g} / \mathrm{m} 3)$ of NO2 in both cities, both in urban and suburban communities, is below the annual limit value $(40 \mu \mathrm{g} / \mathrm{m} 3)$.

The concentration of SO2 in the air in both the ports of Drenas and Pristina is within given standards by the Directive 2008/50 / EC on air quality. At the monitoring station in Drenas in the monitoring period during 2011, the concentration of SO2 is higher compared to the SO2 concentration at the monitoring station in Pristina during the same year. 


\section{Reference}

8. . Ashraf, M.A., Maah M.J and Yusoff, I.B. Study of Water Quality and Heavy Metalsin Soil \& Water of Ex-Mining Area Bestari Jaya, Peninsular Malaysia, 2010.

9. . Air Quality Resources. (2011) Concern for the Environment: air Quality in the Cement and Construction Industrycleantechindia.com/eicimage/2102_42/PPACI.htm. 2004

10. . US Environmental Protection Agency. (2010) Available and Emerging Technologies for Reducing Greenhou Gas Emissions from the Portland Cement Industry, North Carolina, USA.

11. . HEINRICH, M. PITZ, W. BISCHOF, N. KRUG (2003): Endotoxin in fine (PM2.5) and coarse (PM2.5- 10 particle mass of abmient aerosols, A temporo-spatial analysis, Atmos. Environ. 37. 5.POPE B., BATES V. (1995): Health effects of particulate air pollution: time for reassessment.

12. . WORLD HEALTH ORGANIZATION-WHO (1999) Monitoring ambient air quality for impact assessmentWHO Regional Publication European Series, No. 85. 